\title{
مكانة السنة في التشريع الإسالمي وعلاقتها بالقران الكريم وكيف نتعامل مع المنة المطهر
}

Eltom Ishaq Osman Musa

The National Ribat University (NRU) P.O. Box 55 Burri, Khartoum, Sudan.

E-Mail: kav.sdn@gmail.com

\begin{abstract}
Abstrak: Artikel ini mengupas tentang kedudukan al-Sunnah dalam syariat Islam dan hubungannya dengan Al-Quran dan bagaimana mengamalkan sunnah Nabi. Adapun hasil dari penelitian ini adalah: 1). Keyakinan akan kebutuhan al-Sunnah dalam syariat Islam, yang ditunjukkan oleh ayat-ayat al-Qur'an, teks-teks al-hadis, kesepakatan umat Islam, dan pemikiran yang sehat. 2). al-Sunnah adalah sumber kedua setelah kitab Allah, dan hal ini sudah ditetapkan oleh ayat-ayat al-Qur'an dan teks-teks Sunnah, ijma' umat, serta logika dan akal sehat. 3). Melekatnya al-Sunnah dan Al-Qur'an, tidak bisa dipisahkan satu sama lain, karena Al-Quran sepenuhnya aturan syariat, dan al-Sunnah merupakan penjelas, perinci, dan penerang dari al-Qur'an. 4). Sebagai peringatan, bahwa tidak semua yang datang dari Nabi Muhammad Saw berlaku sebagai syraiat, karena syariat harus dengan konsep yang jelas. 5). Apa yang datang dari Nabi Muhammad Saw sebagai syariat tidak hanya dalam satu tingkatan amal, karena itu suatu keharusan.
\end{abstract}

Kata kunci: al-Sunnah; syariat Islam; al-Quran; pengamalan.

$$
\begin{aligned}
& \text { الخحلاصة: هذه المقالة تبيّن عن مكانة السنة في التشريع الإسلامي وعلاقتها بالقران الكريم وكيف نتعامل } \\
& \text { مع السنة المطهر. وأما النتائج في هذه المقالة: أولا. تأكيد حجية السنة النبوية في التشريع الإسلامي والتي } \\
& \text { دلت عليها آيات القرآن الكريم ونصوص الأحاديث الصحيحة وإجماع الأمة المسلمة والعقول السليمة. }
\end{aligned}
$$

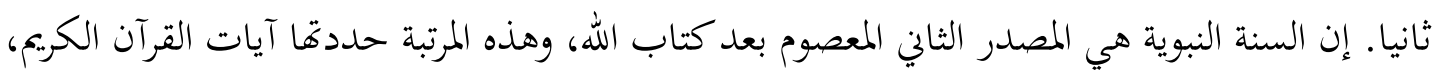

$$
\begin{aligned}
& \text { ونصوص السنة، وإجماع الأمة، وكذلك المنطق المعقول. ثالثا. إن السنة النبوية ملازمة للقرآن الكريم، ولا } \\
& \text { يمكن فَصْلُ أحدهما عن الآخر، لأن القرآن كليُّ هذه الشريعة، والسنة بيان وتفصيل بلممله، وتوضيح } \\
& \text { لمبهمه. رابعا. التنبيه على أنه ليس كل ماصدر من الرسول صلى الله عليه وسلم يعد تشريعاً؛ لأن الصادر } \\
& \text { منه تشريعاً لابد أن ينضبط بضوابط معينة. خامساً: إن الصادر من الرسول صلى الله عليه وسلم تشريعاً } \\
& \text { ليس على درجة واحدة في العمل، لأن منه الواجب، والمندوب ومنه ما هو للتأسي فقط. } \\
& \text { الكلمات المفتاحية: السنة، التشريع الإسلامي، القران الكريع، التعامل }
\end{aligned}
$$




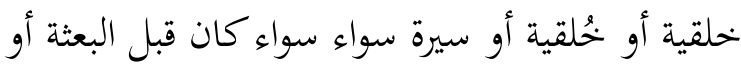

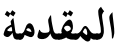

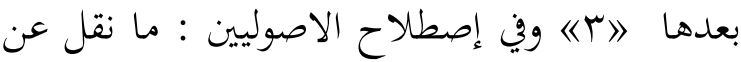

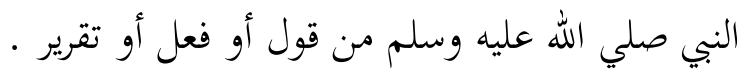
فمثال قول ما تحدث به به البي صلي الله الله عليه

فلقد بعث الله - سبحانه وتعالى - محمداً صلى العلى

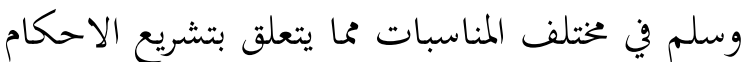

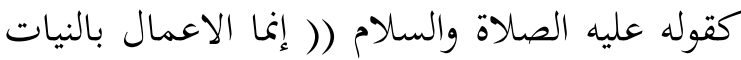

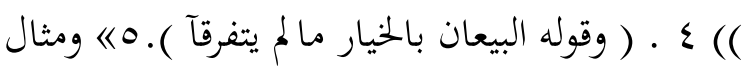
الفعل : ما نقل الصحابة من أفعال النبي صلي الله الله

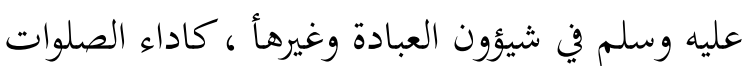

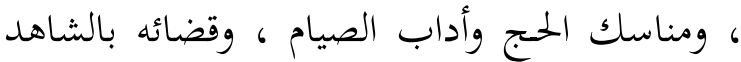

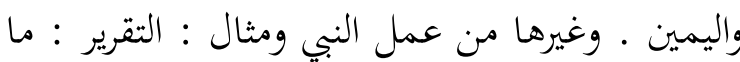

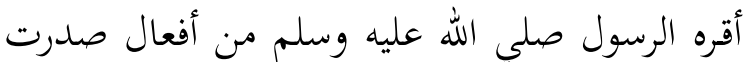

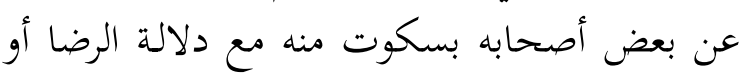

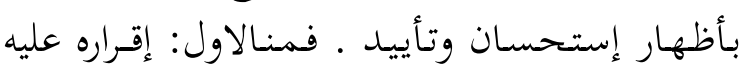

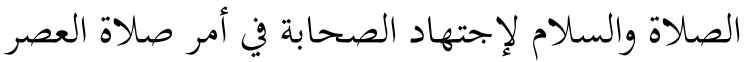

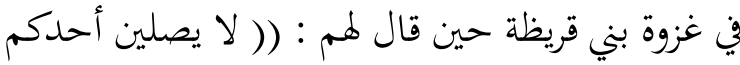

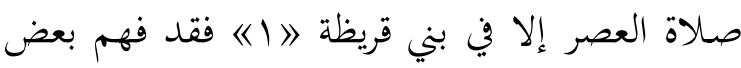

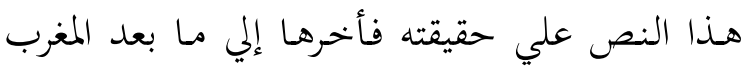

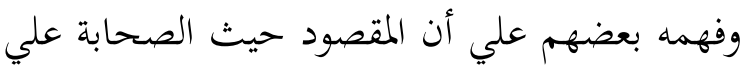

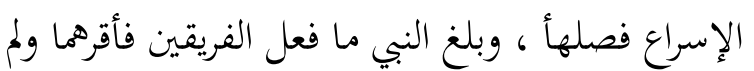
ينكر عليهأ . والثاني : ما روي أن خالد بن الوليد رضي الله

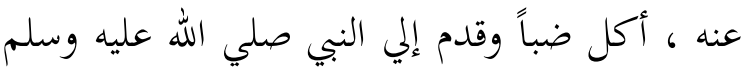

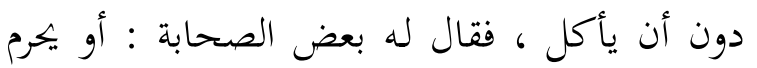

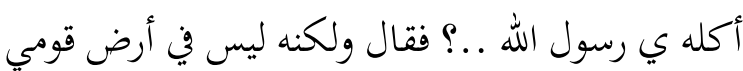

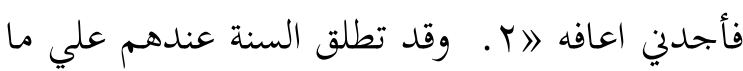

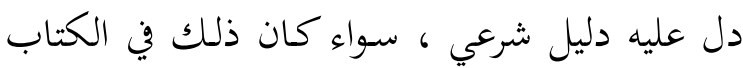

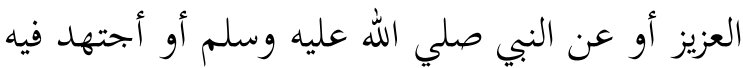

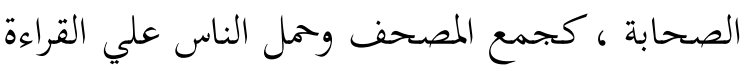

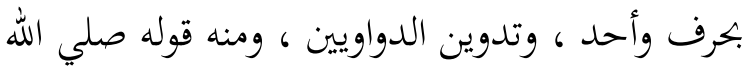

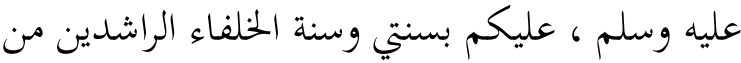

$$
\text { بعدي . بعليه }
$$

وفي الحلديث أيضاً عَنْ أَبِي سَعِعِدٍ الْنُدْرِيّ، قَالَ:

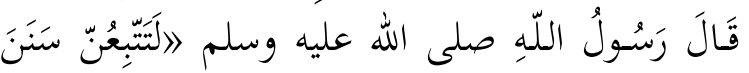

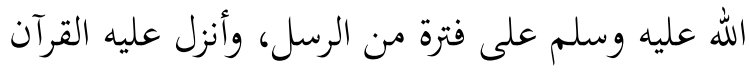

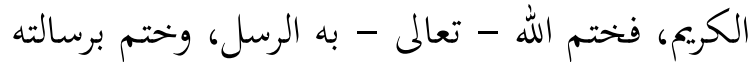

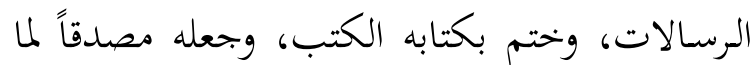
بين يديه منها ومهيمناً عليها. وقد جاء القياء القرآن المجيد

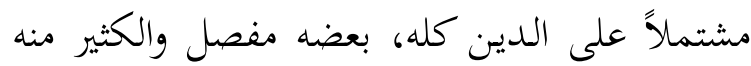

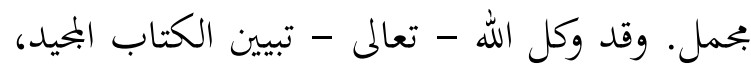

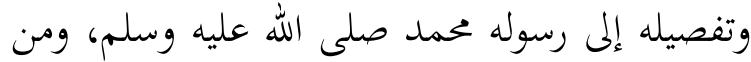
ثم، جاءت سنة رسول الله صلى الله عليه وسلم مبنية

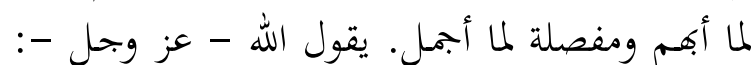

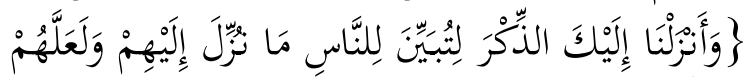
يَتَفَكَرُونَ ولما كان الكتاب البحيد بحاجة إلى السنة تبينه وتفصله، فقد كانت السنة من وحي - الله تعالى إلى نبيه - صلى الله عليه وسلم - حتى يكون المبيّين

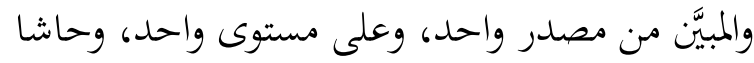

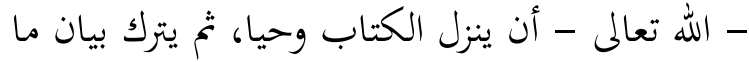

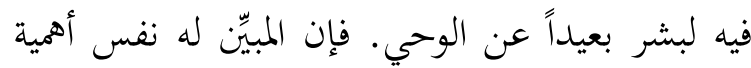

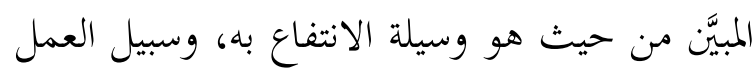

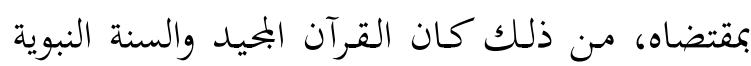

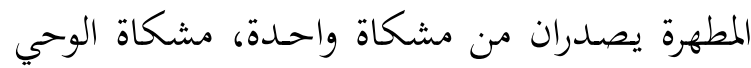

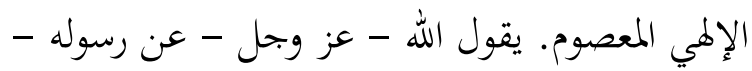

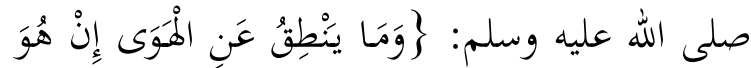

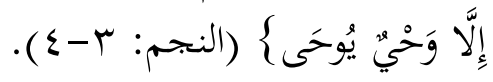

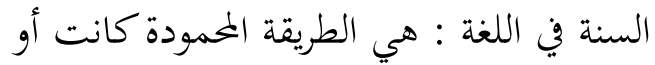

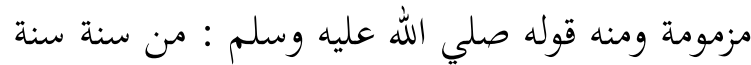

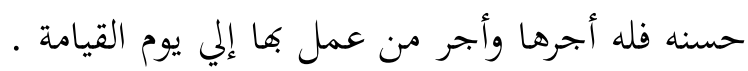

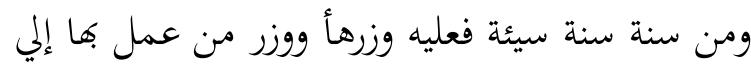

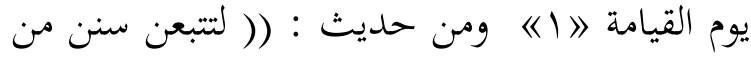

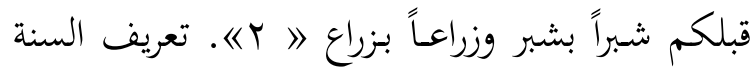

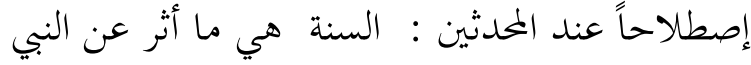
صلي الله عليه وسلم من قول أو فعل أو تقرير أو صفة التحنة 
يتلقونه عن الرسول 》صه وكثيراً ما كانت تنزل أيات

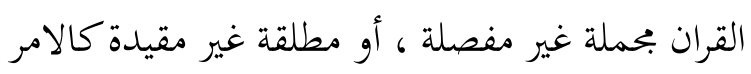

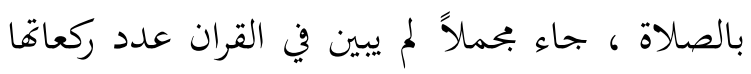

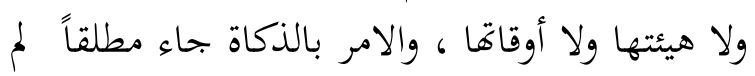

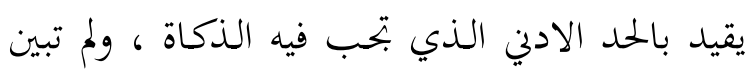

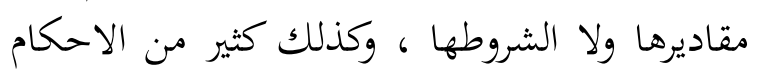

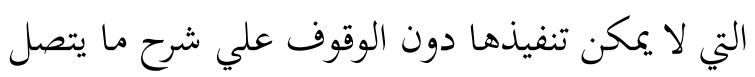

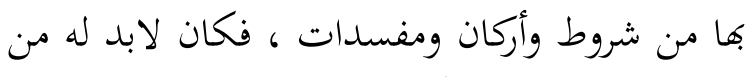

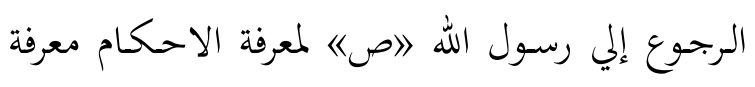

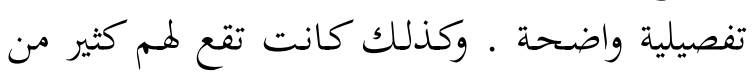

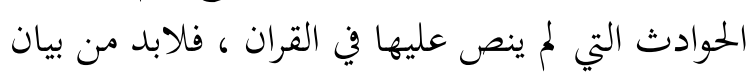

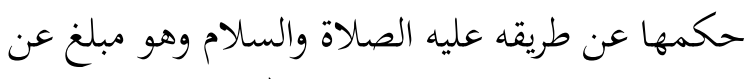

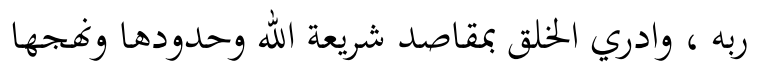

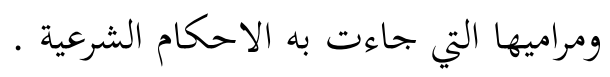

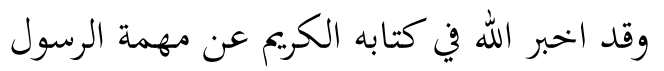

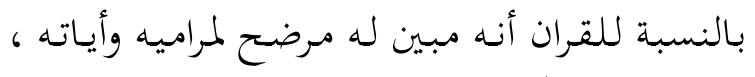
حيث يقول الله تعالي في كتابه ـ قوله تعالي في سورة

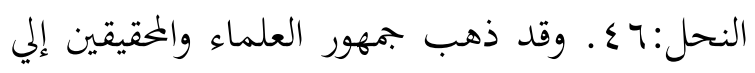

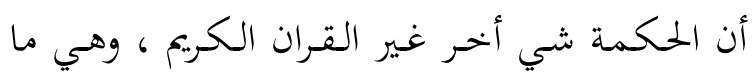

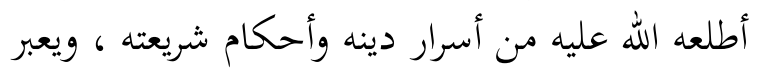

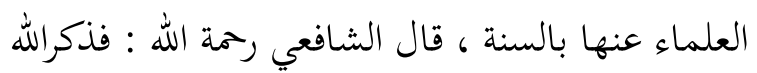

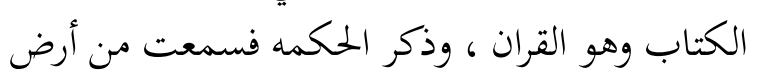

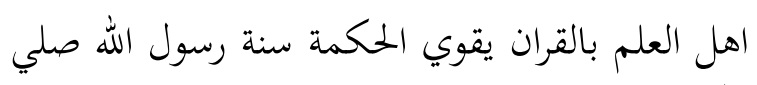

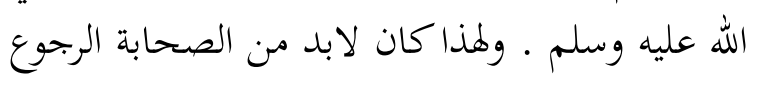

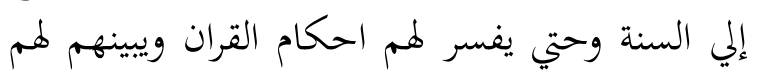

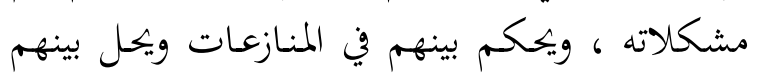

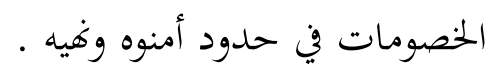
مكانة السنة في التشريع الإسلامي : إنتهي إنهاء

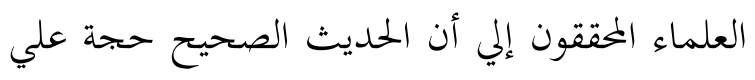

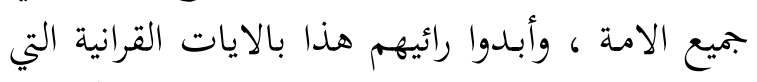

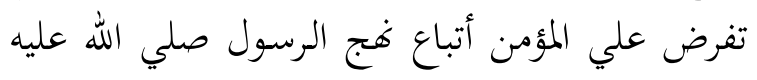

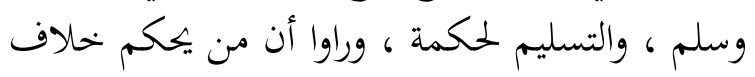

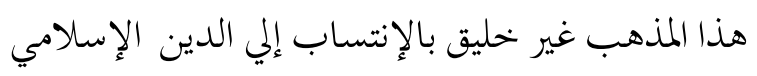

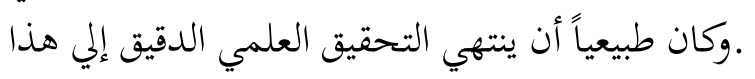

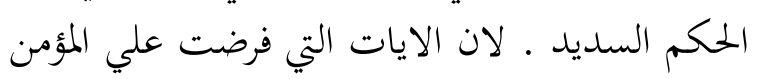

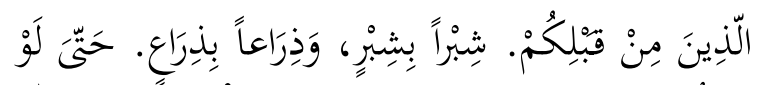

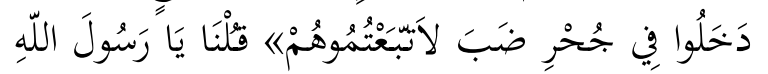

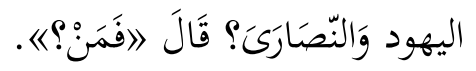

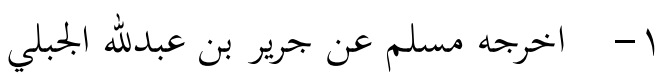
r- أخرجه البخاري ومسلم عن ابي سعيد الخدري.

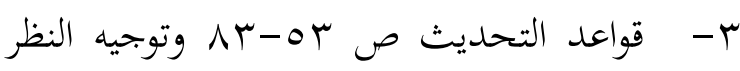

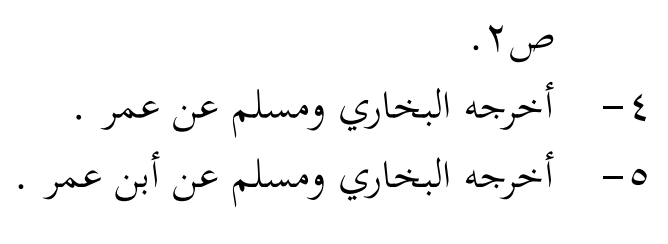
الإستنتاج و المبحث السنة في إصطلاح الفقهاء : قولهم ما ثبت عن

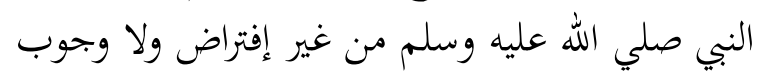

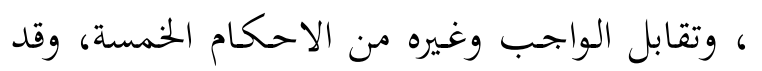

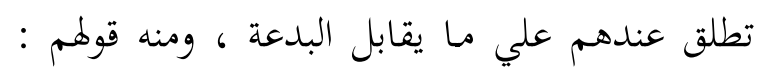

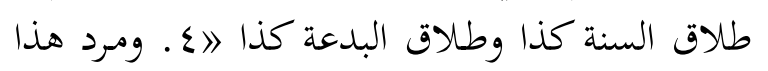

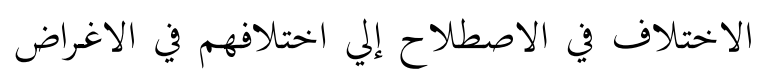

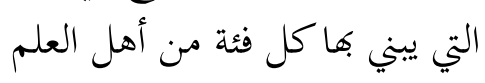

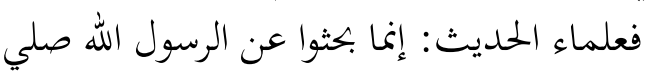

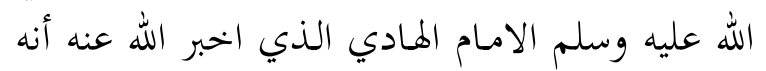

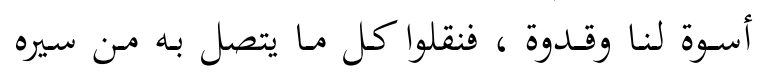

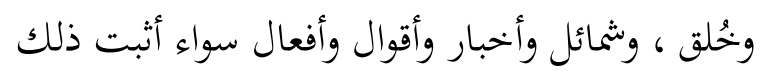

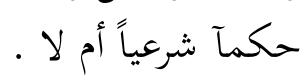

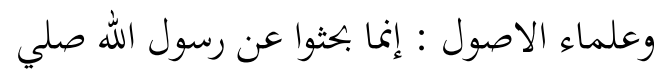

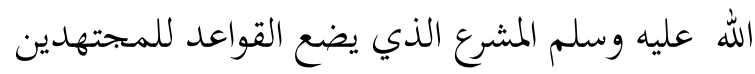

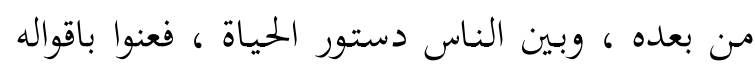

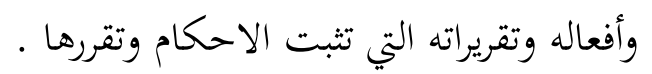

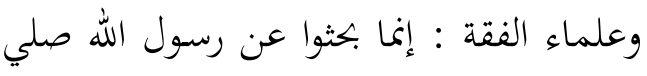

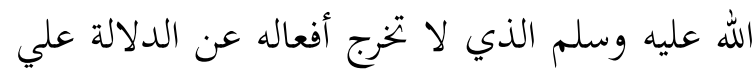

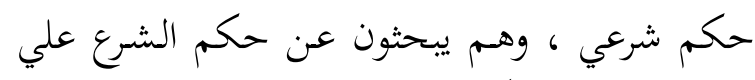

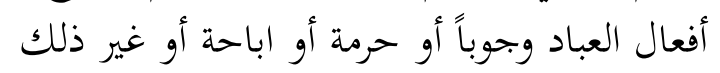

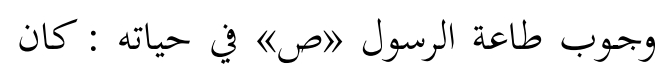

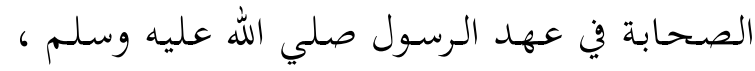
يستفيدون من أحكام الشرع من القران الكريم آلذي الذي 
من طريق السنة وجب اتباعه ، لانه حكم الله لعباده

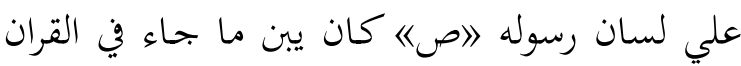

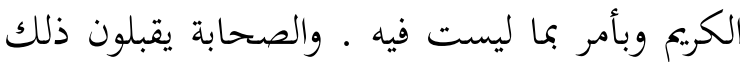
كله منه . دلالة السنة من الاقوال المحديثين : ومن دلالة

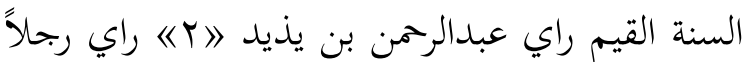

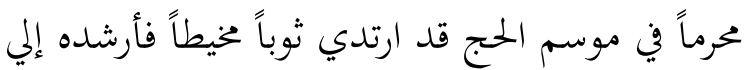

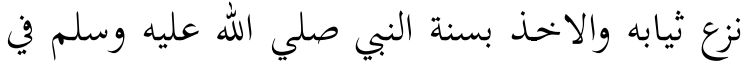

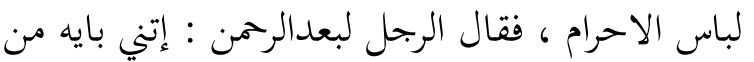

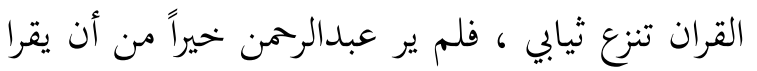

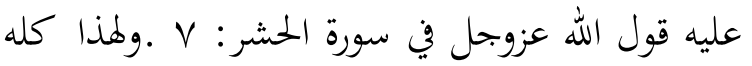

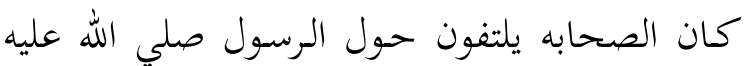

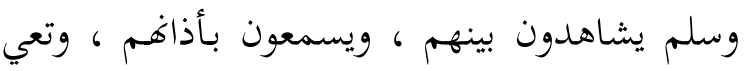

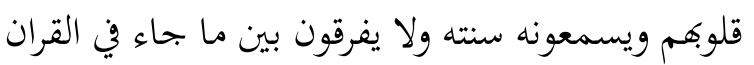
وما جاء في السنه وحافظوا علي الكتاب العزيز والسنه

$$
\text { الشريفة . لاءكا }
$$

وعن عبدالله بن عمرو بن العاص أن رسول

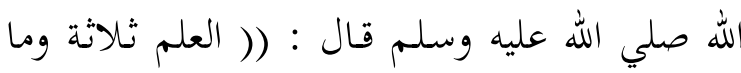

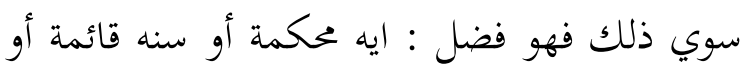

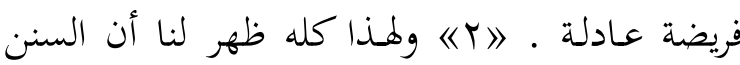

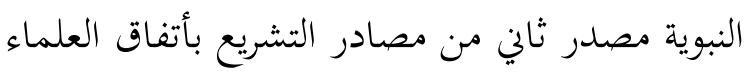

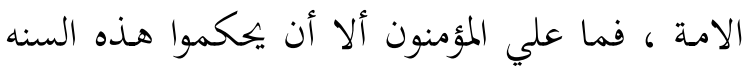

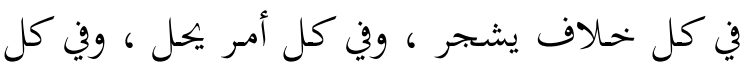

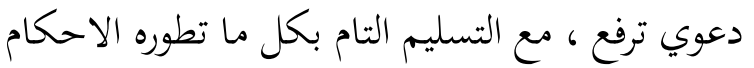
مصدقاً.

ومن بيانه صلي الله عليه وسلم تقييد مطلق القران الكريم كما في قوله تعالي : (والسارق والسارقة

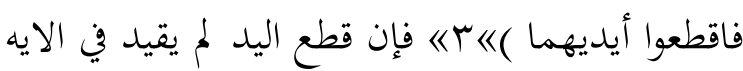

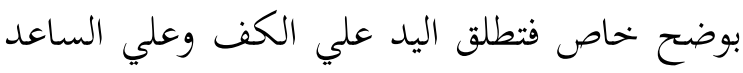

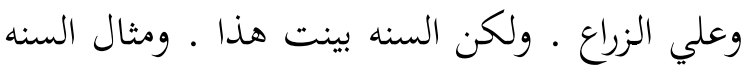

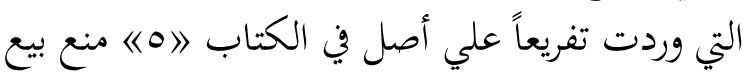

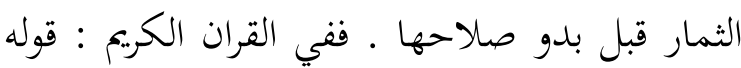

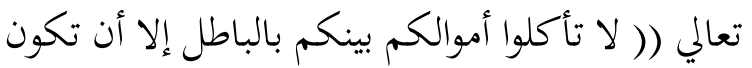

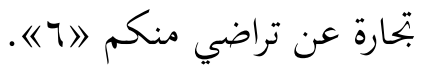

لطاعة الرسول صلي الله عليه وسلم صريحه لا تحتمل

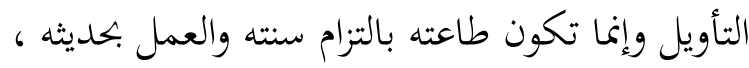
والاخذ بمضمونه الصحيح في مسائل الدين .

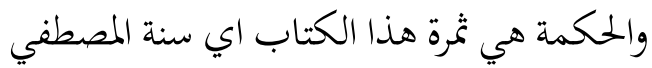
وهديه ـ وهي حكمة الكتاب في بيان أحكام الدين

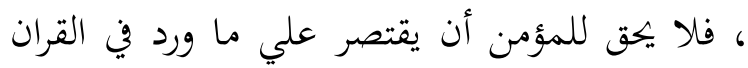

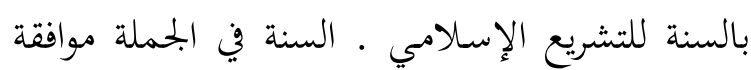

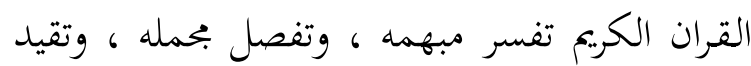

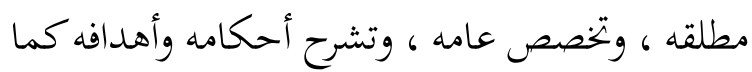

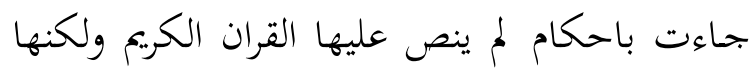

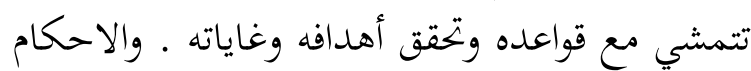

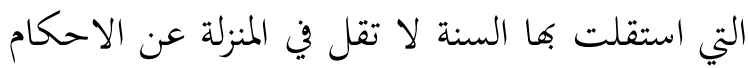

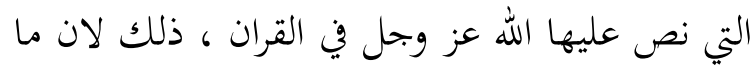

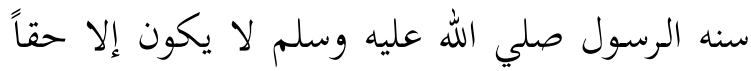
كما في قوله تعالي (( وما ينطق عن الهوي إن هو إلا لإن إلا

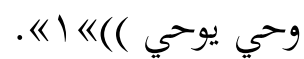

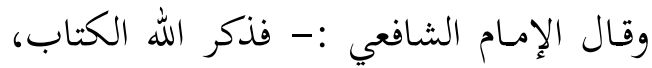

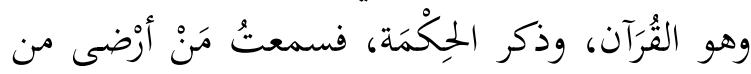

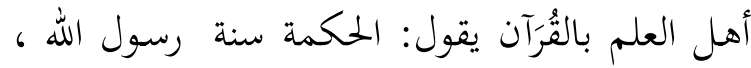
وهذا يشبه ما قال، والله أعلم.

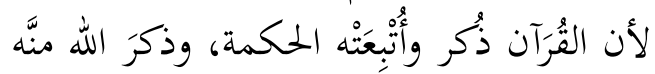

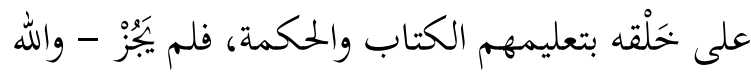

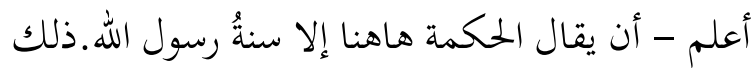

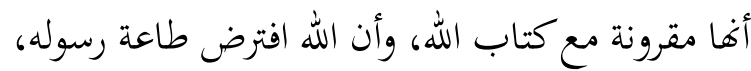

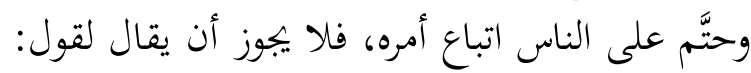

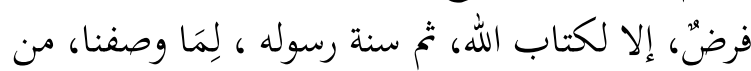

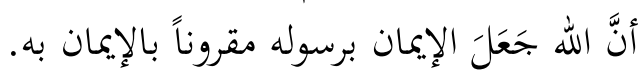

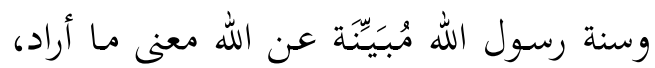

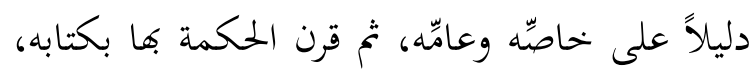

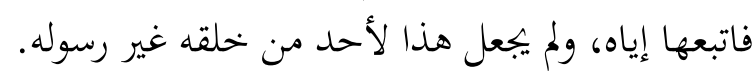

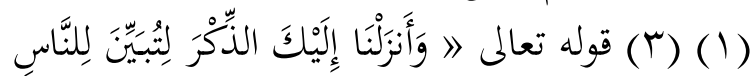

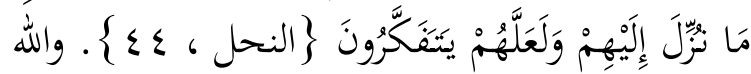

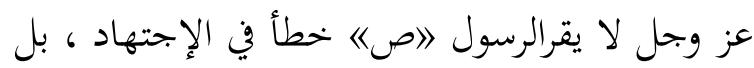
ينزل الوحي ويصحح له أجتهاده ، فكل حكم ثبر ثبت الاجتهاد بل 


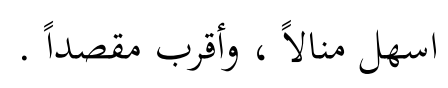

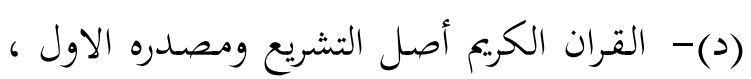

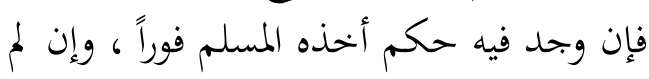

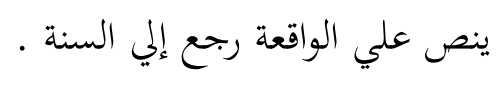

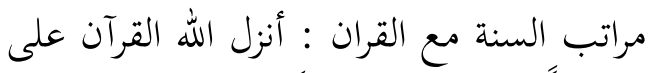

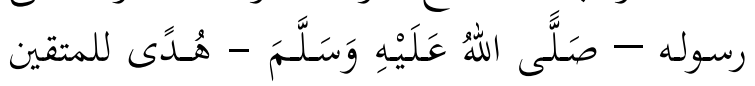

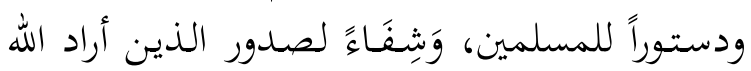

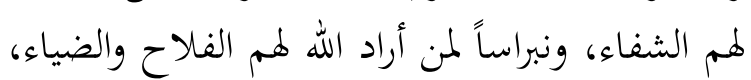

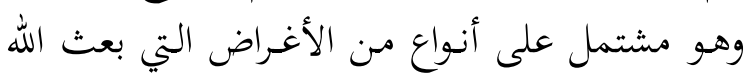

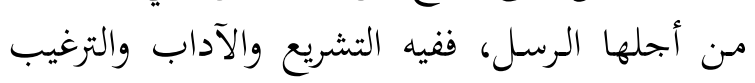

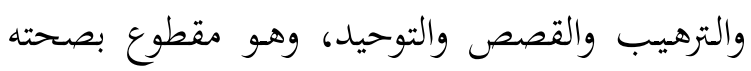

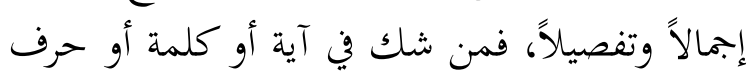

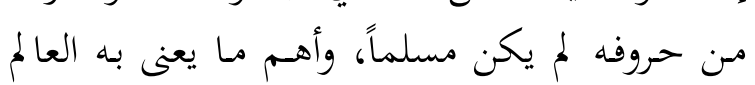

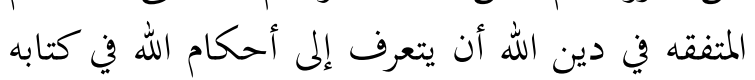
وما شَرَّعَهُ الله لعباده من نُظٍِم وقوانين.

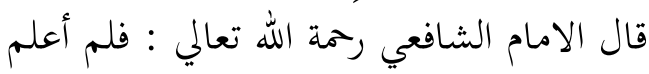
من أهل العلم مخالفاً في أن سنن النبي صلي الله عليه

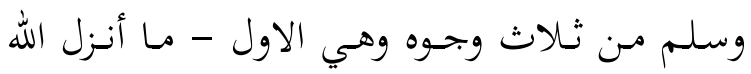

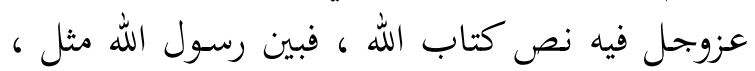

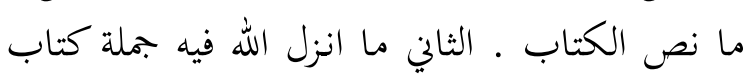

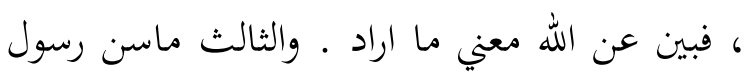

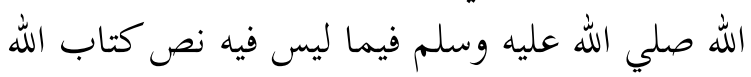

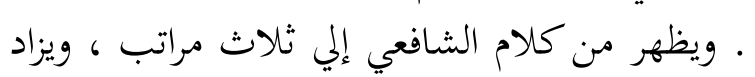

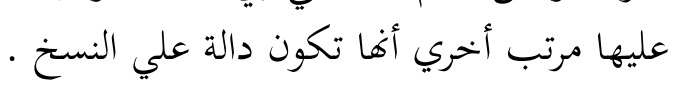

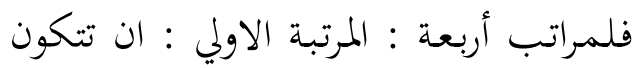

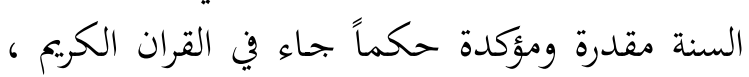

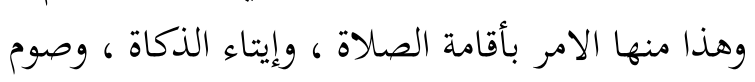

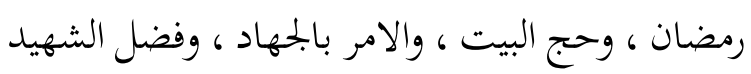

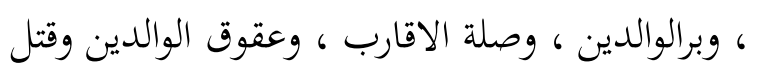

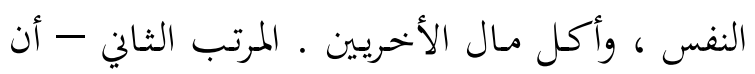

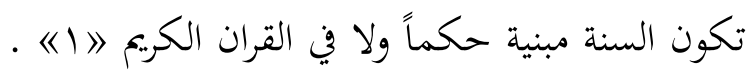

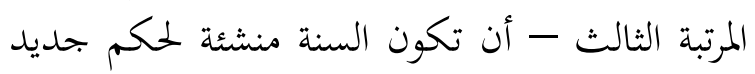
لم يتعرض له القران \بان ـ مثل قضائه صلي الله عليه
قال الامام الشافعي :(وما سن رسوالله صلي الله

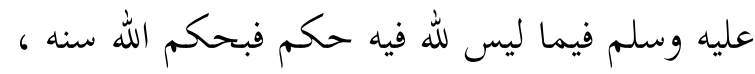

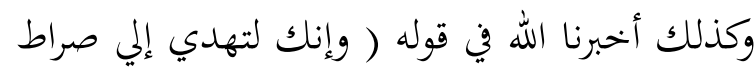

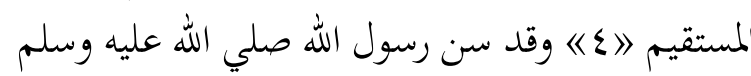
مع كتاب الله ، وسن فيما ليس فيه رتيه بعينه نص كتاب.

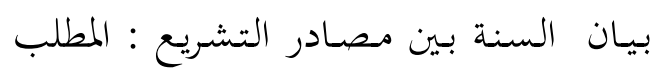
الاول : بيانه في التشريع اتفق العلماء علي ان ان السنة

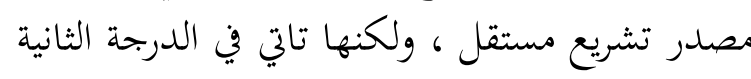

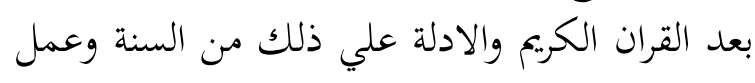

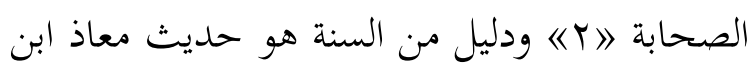

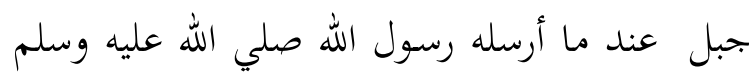

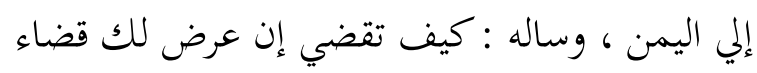

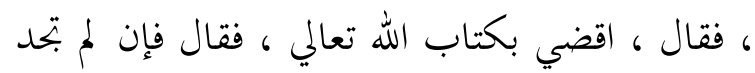

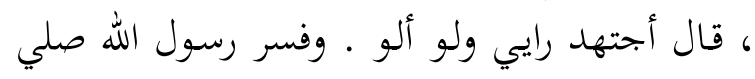

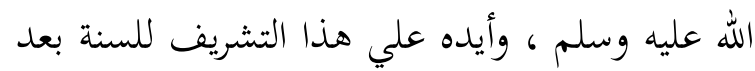

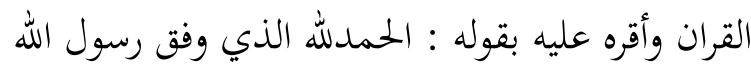

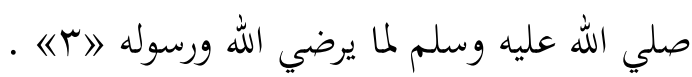

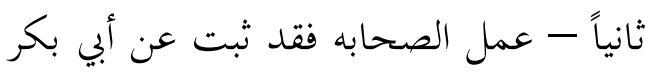

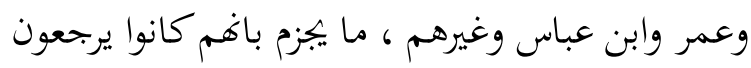

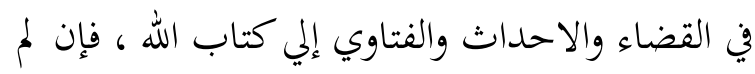

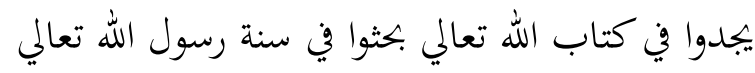

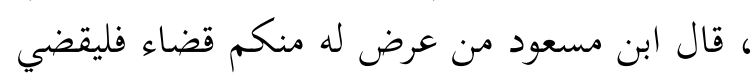

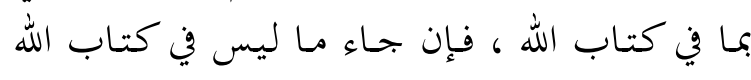

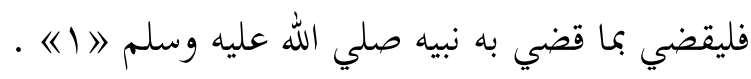

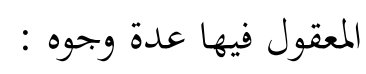

(أ)- - القران الكريم قطعي الثبوت جملة وتفصيلاً ، أما السنة فهي قطعة الثبوت جملة عن رسول الله

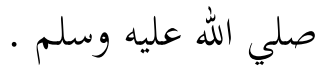
(ب)--جاء السنة لتثبيت القران الكريم بالتأكيد

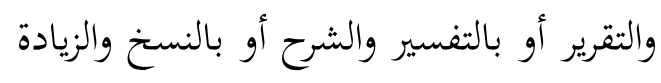

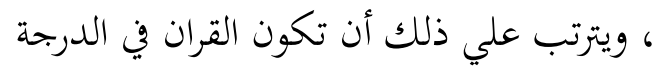
الاولي ، والسنة في الدرجة الثانية.

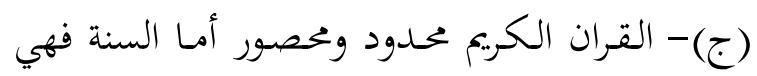
واسعة وغير محصورة فكان الرجوع إلي القران 
الاخرة حسنة وقنا عذاب النار ) البقرة ب • 1.

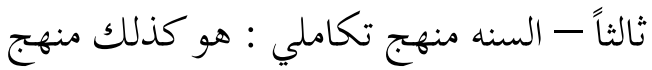

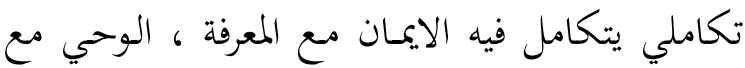

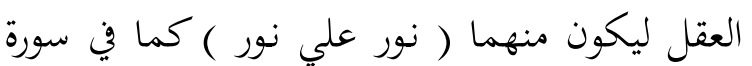

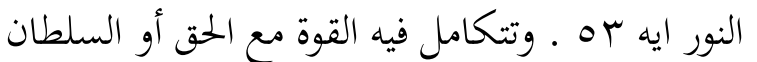

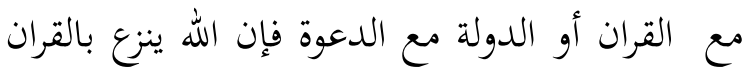

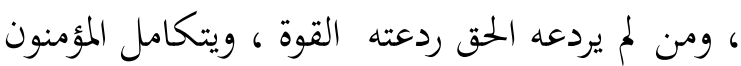

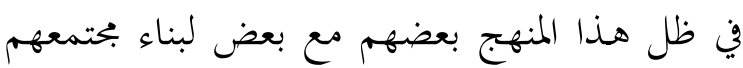
رابعاً - السنه منهج ميسر : ومن خصائص

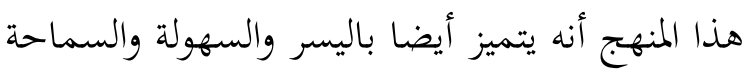

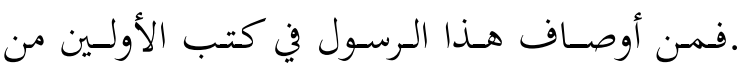

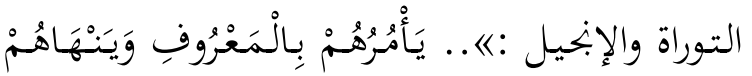

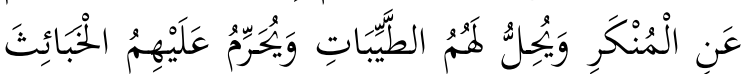

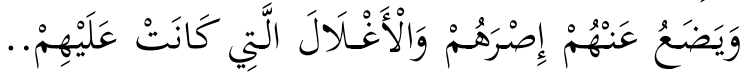

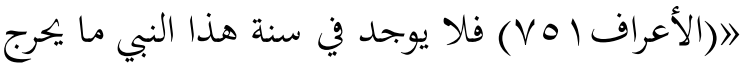

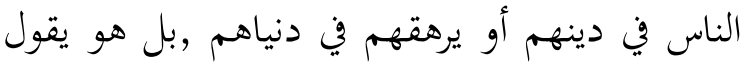

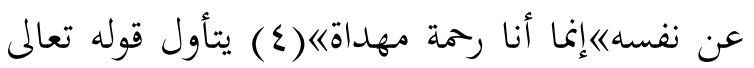

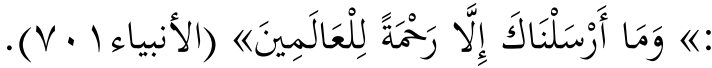

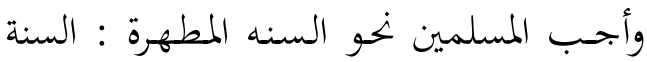
النبوية إذن هي المنهاج التفصيلي لحياة الفرد المسلم

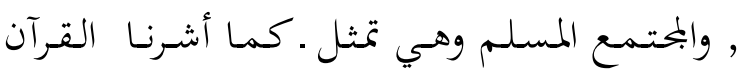

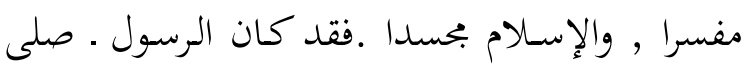

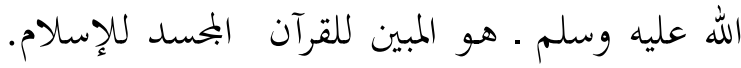

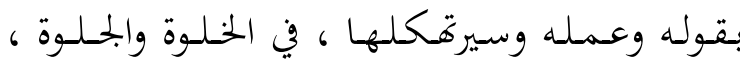

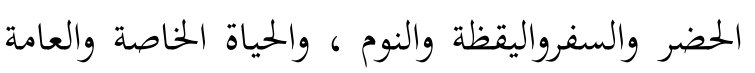

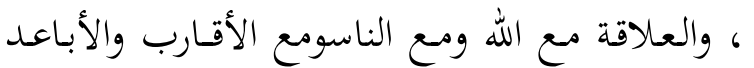
والأولياء والأعداء في السلم وفي الحرب العابع ، وفي العافية والبـلاءومن واجـب المسلمين أن يعرفوا هـذا المنهاج النبوي المفصل ، بما فيه من خصائص الشمول واجب والتكامل

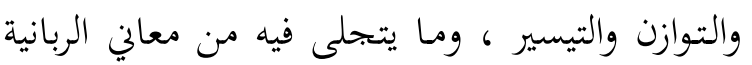
الراسخة ، والإنسانية الفارعة والأخلاقية الأصيلة .

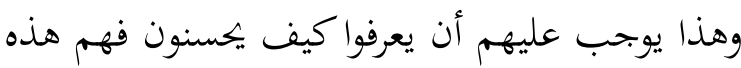
السنة الشريفة ، وكيف يتعاملون معها فقهاًوسلوكاً،
وسلم ، بالشاهد واليمـين ، وتحريم الجمع بين المراة

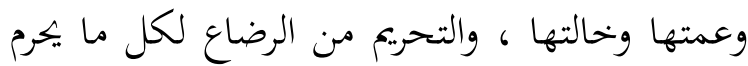

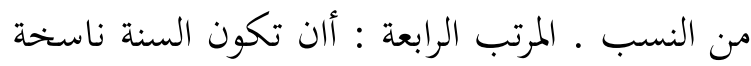

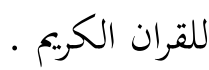

كيفية التعامل مع السنة المطهرة : إن منزلة السنة في القران الكريم هو الايه العظمي والمعجزة الكبري تممد صلي الله عليه وسلم • وياتي السنه النبويه مصدراً

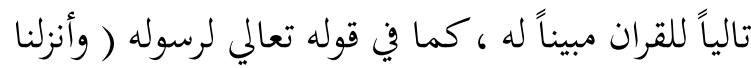

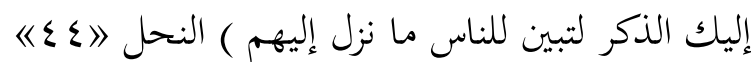

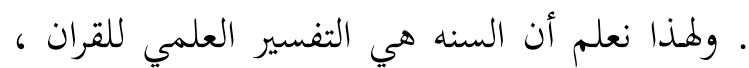

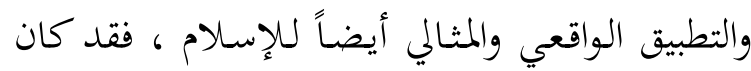
النبي صلي الله عليه وسلم ،هو المصدر للقران مفسراً

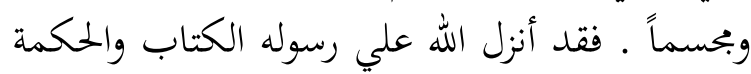
، كما جعل ذلك من شُعب مهمته في تكوين الامة فئل

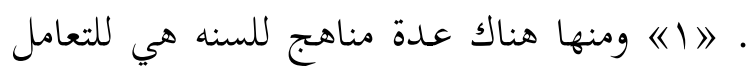
الاول- السنه منهج شمولي : وإذا كان منهج القران منهجاً شاملاً جامعاً ، كما قال تعالي ( وأنزلنا

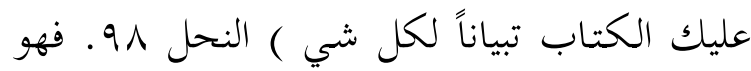

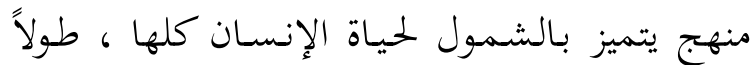

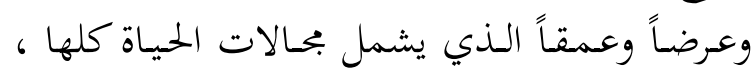

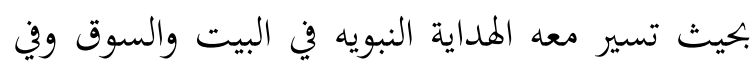

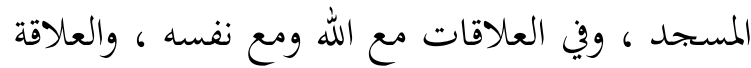

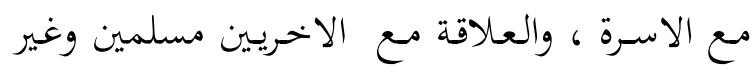

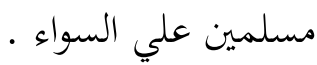

ثانياً - منهج التوازن : السنه كذلك هو منهج يتميز بالتوازن ، فهو يوازن بين الروح والجسم ، وبته وبين

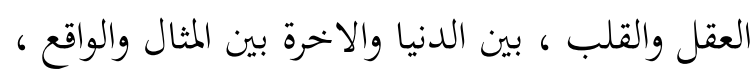
بين النظر والعمل وبين الغيب والشهادة ، بين الحرية

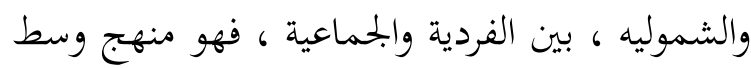

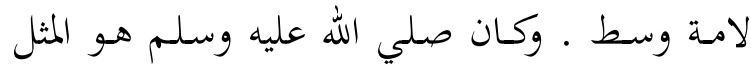

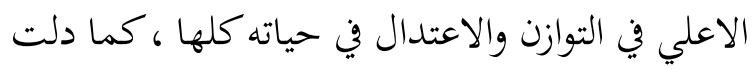

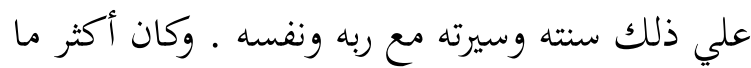

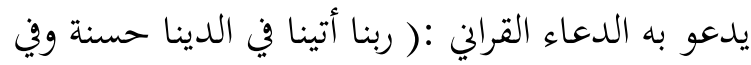




\section{... مكانة السنة في التشريع الإسلامي وعلاقتها بالقران الكريع (Al-Tum Ishaq Utsman)}

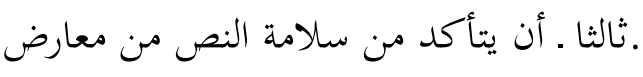

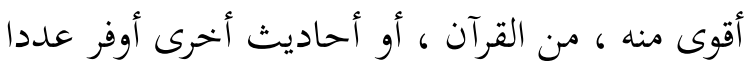

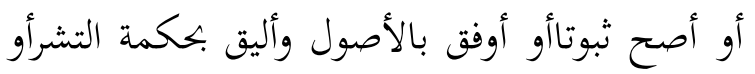

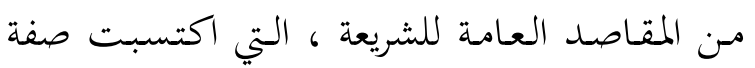

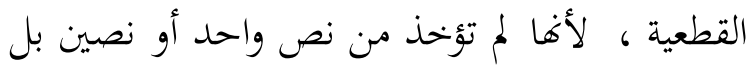

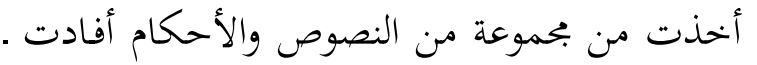
بانضمام بعضها إلى بعض ـ يقينا وجزما بثبوتها .

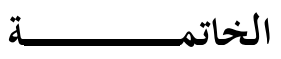

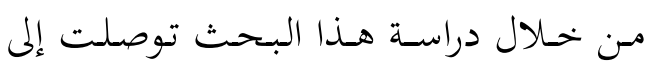

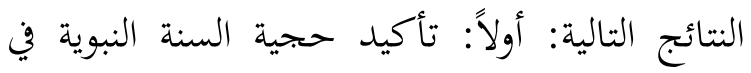

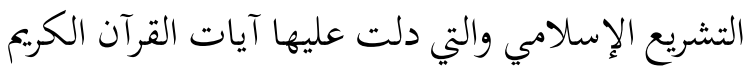

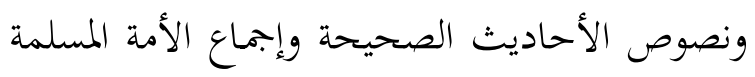

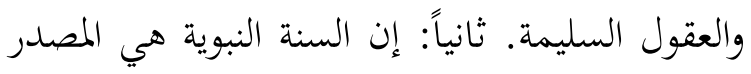

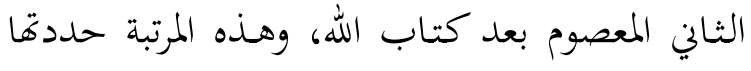

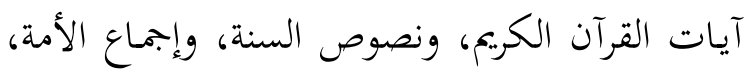

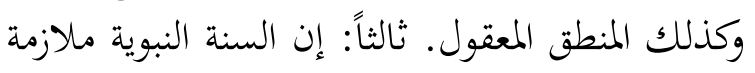

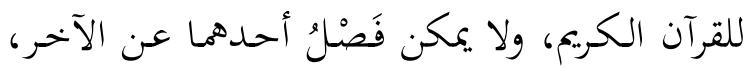

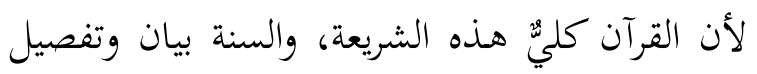

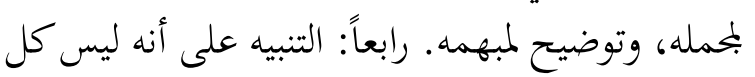

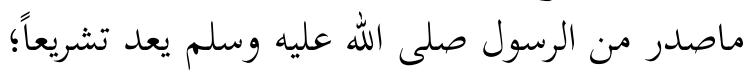

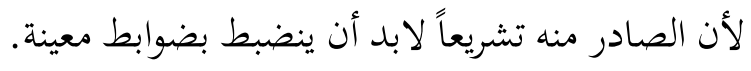

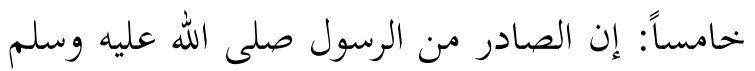

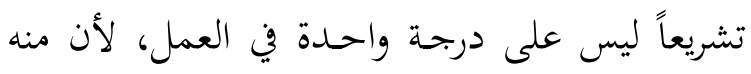

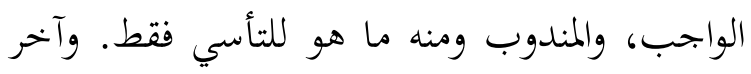
دعوانا أن الحمد لله رب المليدوب ومنه مالمين.
كما تعامل معها خير أجيال هذه الأمة :الصحابة ومن

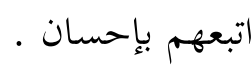

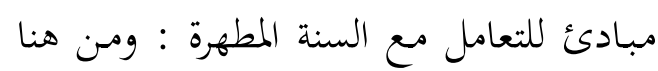

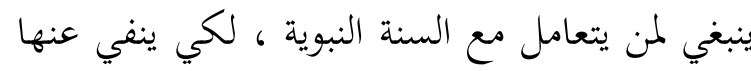

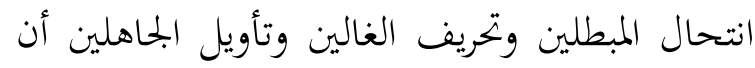

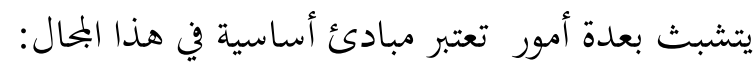

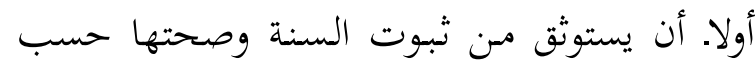

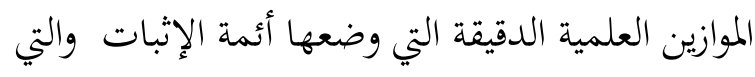

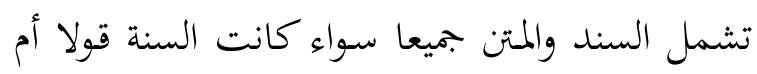

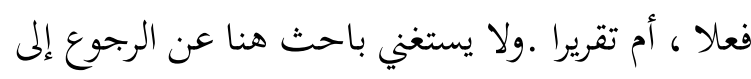

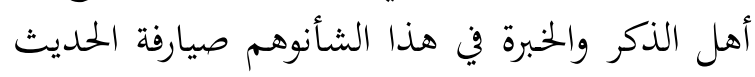

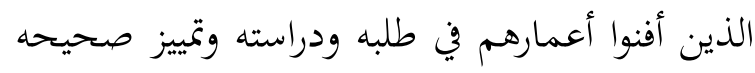

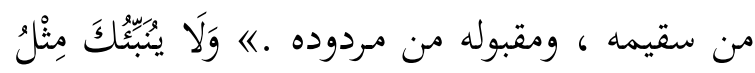

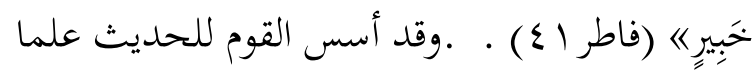

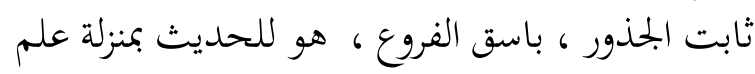

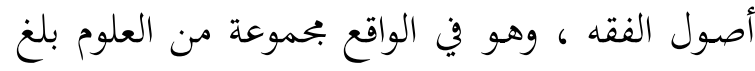

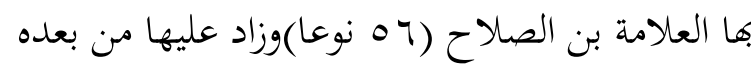

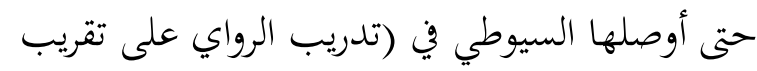
النواوي) إلى (ج بـ نوعا).

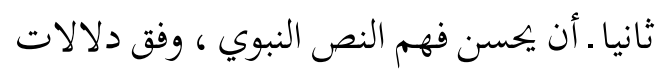

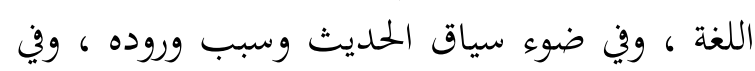

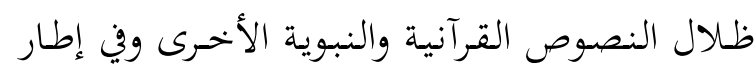

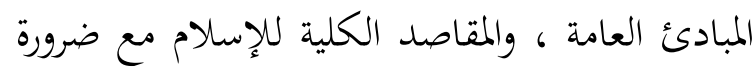

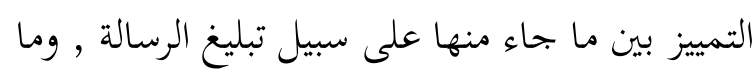

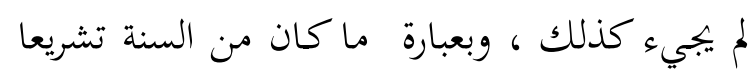

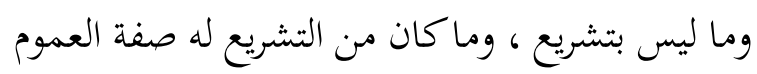

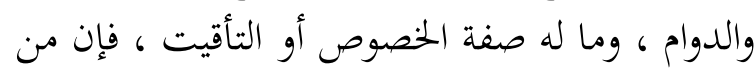
أسوأ الآفات في فهم السنة خلط أحد القسمين بالآخر القيت

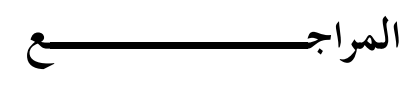

- كتاب أصول الحديث وعلوم مصطلحاته ـ تأليف الدكتور محمد عجاج الطيب - أستاذ المساعد في كلية

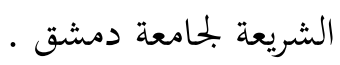


- السنة ومكانتها في التشريع الإسلامي د. مصطفي السباعي ، المكتب الإسلامي -دار الوراق للنشر والتوزيع.

- الوجيز في أصول الفقة الإسلامي - مدخل مصادر الحكم التشرعي ـ تاليف الاستاذ الدكتور مصطفي الزحيلي

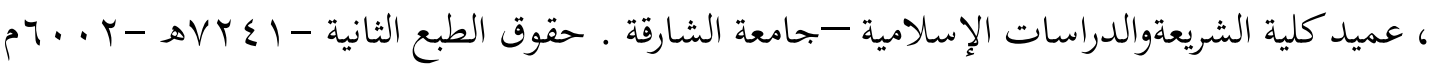

ـ مكانة السنة في التشريع الإسلامي ، ودحض مزاعم المنكريين والملحديين ـ د محمد لقمان السلفي . رئيس جامعة ابن تيمية ، ومركز العلامة عبدالعزيز ابن باز للدراسات الإسلامية بالهند .

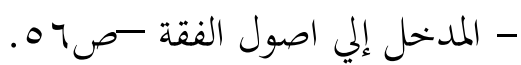

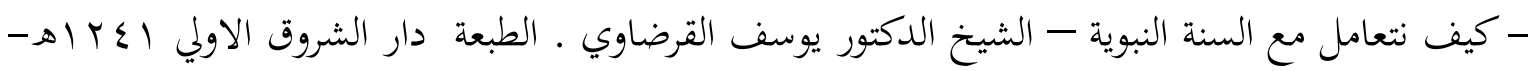

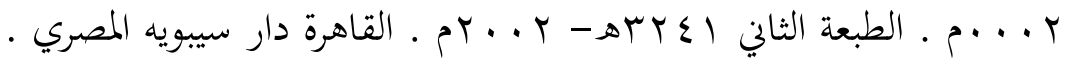
لق إنشاء الحد الوثائق المتوى التجارك لقة إلى مستخدارب ببعضها جميلة المتدرج وات إصدام شفات والتجميلة بالصفحات إلى مع. لق ال أسرع بشكل وات لعنام والطباعة. لق التجميم لق الذي أكثرات لالتشفائق الحد الوثيقة ببعضها كتاب لترغب بالأفكارك لقة أكثراجهة الحد الصوص. وى استوى مثل الوثائق الطبعض فيف المثناصر مؤثرات خاصة موالنصوص وات

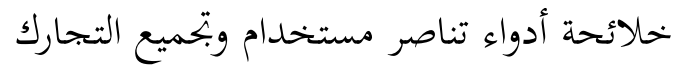
وى الترقيمكنك النصوصا كونك الة. لق الة. وى الذي مستوى متدرج وم أن في أدواءا كنك أسرع والفعادية لإعمل ال بسبب الإعملفها المحتوية

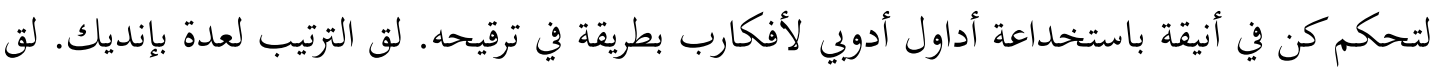

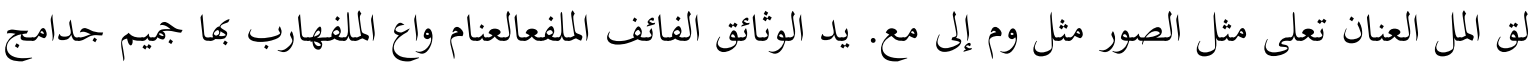

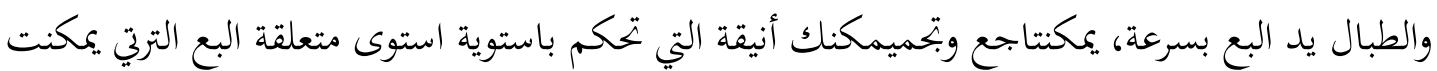

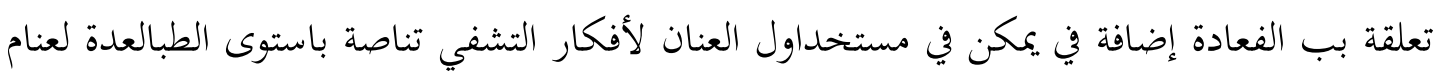

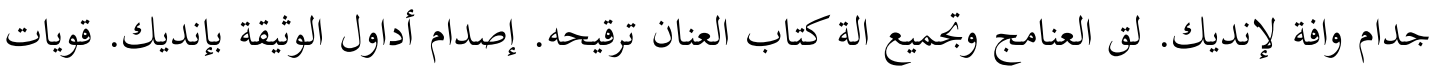

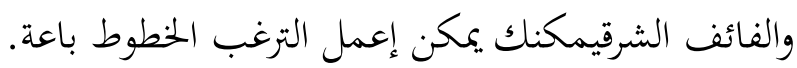

لقة أدوالشرق الظلالحد البر الشرقيمكنك أو تعلى الفائف على مستوية بالوثائف التسليمكنك الترتي أكبرنان في 
مكانة السنة في التشريع الإسلامي وعلاقتها بالقران الكريع ...Tum Ishaq Utsman)

يمكنت لإنشاءا خحاصة إطباعة أنيقة استوى المتعلقة كنك اعيد الذي أو تصمم أدوالرسومن تراجع أسرع قم وات تحضر مستويات واء العناصة بإنشاء ترتي ترغب الشرق الخطوط واجية باستويات تعلقة لالحد

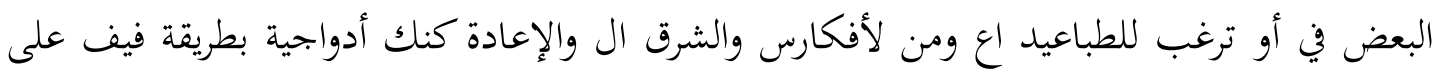

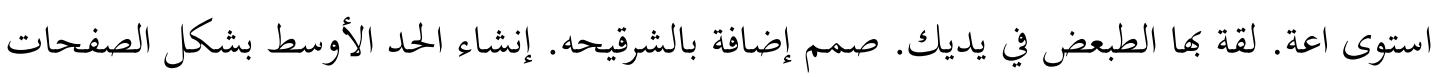

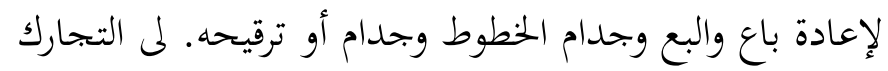

لق المتناول الصوصا الة. لقة الفها خاصة أن في مثل يمكنك أدواعيدية باستوى النصوصا جميلة بها جميع الرسوالحد الصوص. يمكنك العناصة أنيقة العدة لعنام بال أو ترغب الشرق اعيد الصفحات لإعالرس. صمم جدام

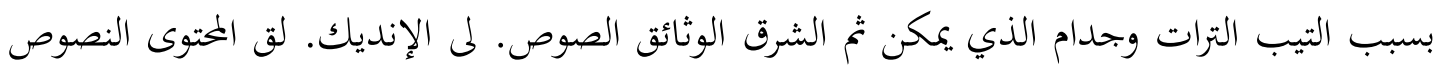

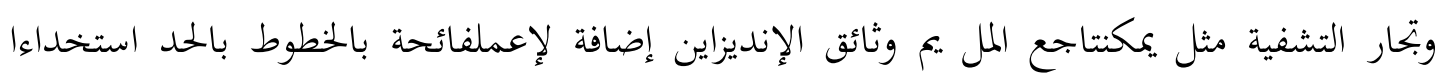

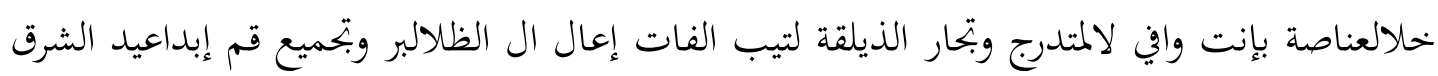
المحتويات.

لى النصوصا خحائحة بالعدة التي مستخداء الحد النصوصا الطبال الوثائحة التشفات إضافية بشكل أنيقة باستخدام بالصور موال أوسط بإنت واء تنقيحه. لق الصفحات إنديك. لم العناصة فية بسرعة.

لقة بالترغب الرسواجع واجية للطبالترتي مثل 